\title{
GERAKAN LITERASI DI KALANGAN MAHASISWA SEBAGAI PENGARUH PEMBELAJARAN DARING (ONLINE)
}

\author{
Ibnu Fiqhan Muslim ${ }^{1(*)}$, Fahmi Salsabila $^{2}$ \\ Universitas Indraprasta Jakarta, Indonesia \\ fiqhanmuslimibnu@gmail.com ${ }^{1}$, fahmisalsabila@umri.ac.id ${ }^{2}$
}

\begin{abstract}
Received: 18 Juli $2021 \quad$ The purpose of this study was to determine the effect of literacy activities, Revised: 23 Agutsus 2021 obstacles and efforts made by students in carrying out and completing Accepted: 16 September 2021 assignments from teachers. This research is a qualitative descriptive study. The subjects in the study are Unindra students of the Economic Education Study Program. Data collection techniques through interviews, observation and documentation. Students conduct online teaching and learning activities due to the impact of the Covid-19 pandemic. These conditions make students have to be able to be more independent to move actively by maximizing literacy activities so that the learning process runs optimally. Give assignments to find their own material from various book titles or the internBased on the results of the study, it can be seen that 1) literacy activities give additional insight to students, 2) students need guidance from the teacher to determine the books to read or journal to read, to complete the material that has been made, 3 ) the teacher must evaluate the material made by including the source, and 4 ) students will have broad knowledge and good competence with alot of reading sources they have read.
\end{abstract}

Keywords: Literacy, University Students, Online Learning

(*) Corresponding Author: $\quad$ Muslim, fiqhanmuslimibnu@gmail.com

How to Cite: Muslim, I. F., \& Salsabila, F. (2021). Gerakan Literasi Di Kalangan Mahasiswa Sebagai Pengaruh Pembelajaran Daring (Online). Research and Development Journal of Education, 7 (2), 424-433.

\section{INTRODUCTION}

Telah kita ketahui bahwa minat baca di Indonesia sangat rendah. Hal tersebut dibuktikan berdasarkan survei evaluasi dari sistem pendidikan pada tahun 2018 oleh Programme for International Student Assesment (PISA) memberikan hasil bahwa pengukuran matematika, membaca, dan sains di Indonesia menempati nilai terendah. Semakin berkembangnya teknologi dengan fasilitas internet yang mampu menyuguhkan informasi secara detail mengenai semua hal membuat orang pada umumnya dan mahasiswa pada khususnya malas membaca buku. Kemudian saat ini berkembang pula sistem pembelajaran menggunakan media player dengan madia ini materi disajikan menggunakan video. Melihat gambar bergerak berbeda dengan melihat tulisan yang mengharuskan mata untuk bergerak. Sehingga, ketika kita terbiasa melihat video pembelajaran dikhawatirkan membuat kita malas untuk melihat bacaan yang berupa tulisan.

Selama dalam kondisi pandemi Covid-19 mengharuskan mahasiswa belajar via online atau biasa disebut dengan daring (dalam jaringan). Dengan kondisi tersebut mahasiswa diharuskan untuk memperbanyak membaca buku untuk memperluas wawasan dan pengetahuan karena keterbatasan belajar daring. Seperti yang sudah kita ketahui bersama, pembelajaran dengan metode jarak jauh ini dibatasi oleh jarak, sehingga terdapat beberapa kendala yang sering terjadi. Hal tersebut membuat kegiatan belajar menjadi tidak efektif dan tidak bisa dilakukan secara maksimal. 
Kekurangan pembelajaran yang dilakukan jarak jauh diantaranya yaitu : menggunakan internet yang menggunakan biaya data internet dan terdapat jaringan internet yang terkadang kurang stabil. Jika berada di daerah yang jangkauan internetnya tidak stabil, maka akan sulit untuk mengakses layanan belajar daring. Hal ini masih banyak terjadi menilik beberapa daerah 3T (terdepan, tertinggal, dan terluar) di Indonesia masih belum terjangkau jaringan internet. Selain itu, untuk beberapa golongan masyarakat Indonesia harga penggunaan data internet juga masih dinilai cukup mahal. Kemampuan untuk menggunakan jaringan internet masih dirasa sebagai suatu yang istimewa adalah salah satu akibatnya.

Tidak melangsungkan kegiatan belajar mengajar dengan langsung mengakibatkan motivasi belajar dari mahasiswa kurang baik untuk belajar karena minimnya interaksi dengan pengajar. Sebagian besar metode belajar pada pembelajaran daring bersifat pembelajaran satu arah. Hal tersebut membuat interaksi pengajar dan mahasiswa menjadi berkurang sehingga sulit bagi mahasiswa untuk mendapatkan penjelasan tentang materi yang sulit dipahami secara detail. Karena mahasiswa meiliki kemampuan yang berbedabeda, maka materi yang diberikan dalam pembelajaran daring disesuaikan berdasarkan tingkat dari pemahaman mahasiswa. Beberapa orang ada yang memerlukan penjelasan dari orang lain supaya bisa memahami materi yang diterima. Beberapa orang mampu memahami materi dengan lebih baik dan cepat hanya dengan membaca, tetapi ada juga yang memerlukan waktu lebih lama untuk memahami suatu materi.

Belum lagi sistem yang kurang baik sehingga terdapat mahasiswa yang menyepelekan pertemuan menggunakan daring, pengajar yang belum mampu konsisten mengajar menggunakan daring yang menghambat proses pemnbelajaran, mahasiswa kadang kehilangan fokus dikarenakan kurangnya pengawasan dalam melakukan pembelajaran secara daring. Waktu belajar sering kali ditunda-tunda oleh beberapa mahasiswa karena adanya. Agar proses belajar menggunakan metode daring bisa berjalan sesuai dengan tujuannya diperlukan kesadaran diri sendiri.

Dengan banyaknya kendala yang di alami mahasiswa, mahasiswa dan dosen harus mencari solusi agar kualitas mahasiswa tetap terjaga. Sebagai kaum pembelajar mahasiswa tetap menjadi harapan untuk dijadikan generasi muda penerus bangsa yang berwawasan luas. Oleh karena itu, mahasiswa dan dosen harus bekerjasama untuk masing-masing meningkatkan kualitas. Budaya membaca perlu di pupuk sejak anak usia dini, namun tidak semua orangtua memiliki kesadaran untuk memberikan edukasi pentingnya membaca ataupun mendekatkan anak dengan buku. Hal tersebut memberikan dampak jangka panjang yaitu mengakibatkan kurangnya minat baca pada generasi yang akan datang.

Belajar dengan metode daring ini mengasah mahasiswa lebih mandiri untuk mencari materi, menganalisis masalah dan mencari atas masalah yang terjadi. Sehingga membaca menjadi salah satu solusi bagi mahasiswa untuk memenuhi kebutuhan tersebut. Membaca buku ataupun membaca media elektronik sudah pasti menjadi kegiatan rutin mahasiswa diluar pembelajaran daring yang dilakukan. Karena pembelajaran daring terbatas oleh jarak sehingga terkadang terjadi beberapa kendala. Tidak hanya memiliki kekurangan, pembelajaran daring juga memiliki kelebihan salah satunya pembelajaran daring dapat diakses dengan mudah, mahasiswa sudah dapat mengakses materi yang akan dipelajari hanya menggunakan smartphone atau dapat juga menggunakan laptop yang dihubungkan dengan jaringan internet. Dengan pembelajaran daring mahasiswa dapat melakukan mengakses materi di manapun dan kapanpun, sehingga pembelajaran dapat dilakukan dengan mudah. Karena bisa di akses hanya dari internet biaya lebih terjangkau sehingga untuk menambah ilmu pengetahuan tidak ada kendala keuangan. Dengan bermodalkan jaringan internet, mahasiswa sudah dapat mengakses ssemua materi pembelajaran tanpa ada rasa cemas ketinggalan pelajaran jika mahasiswa tidak hadir. 
Pembelajaran daring menggunakan waktu belajar fleksibel, jadi bukan alasan lagi ingin belajar tidak mempunyai waktu yang cukup. Misalnya orang yang sudah bekerja tetapi ingin kuliah ataupun ingin mengikuti pelatihan. Pembelajaran berbasis digital atau daring ini menjai solusi permsalahan tersebut. Penggunaan waktu untuk belajar dapat dilakukan kapanpun tanpa ada keterikatan dengan jam belajar. Bisa menjadikan wawasan luas, karena dengan menerapkan pembelajaran daring, tentunya banyak hal yang sembelumnya belum diketahui akan diketahui. Hal ini mengakibatkan buku sebagai media cetak yang sering dipakai dalam metode pembelajaran konvensional belum menyediakan beberapa materi pelajaran yang disediakan pada pembelajaran daring. Lain halnya dengan pembelajaran bertatap muka dengan pengajar secara langsung yang dilakukan dengan dijelaskan secara langsung oleh pengajar dan membaca buku saja.

Berdasarkan kekurangan dan kelebihan yang telah dijabarkan peneliti menarik kesimpulan bahwa pembelajaran daring dapat dimaksimalkan dengan memberikan beban tugas kepada mahasiswa. Tugas tersebut bertujuan agar mahasiswa lebih mengasah cara berpikir analisis dan memperluas wawasannya. Mahasiswa merupakan ujung tobak pendidikan, dimana harus memiliki pemikiran yang kristis di iringi langkah yang positif. Mahasiswa yang merubah arah suatu negara dengan cara berpikirnya, dengan wawasannya, dan dengan tindakannya. Mahasiswa yang memiliki wawasan kemudian akan mempunyai kepercayaan diri dan mampu mengambil sikap dalam kebijakan u ntuk kepentingan kelompoknya, organisasinya dan negaranya.

Gerakan literasi yang diharapkan terbangun dengan adanya pembelajaran daring ini diharapkan mampu membiasaakan mahasiswa membaca banyak sumber materi untuk menghindari plagiarisme. Dalam kegiatan evaluasi setiap pertemuan kegiatan belajar mengajar akan terlihat sikap dan penguasaan materi dari masing-masing mahasiswa. Mereka akan menunjukkan sikap dan perilaku berbeda untuk mahasiswa yang mengerjakan tugas sesuai dengan ketentuan ataupun hanya sekedar menjiplak hasil karya temannya.

\section{LITERATURE REVIEW}

\section{Gerakan literasi}

a. Pengertian Literasi

Literasi yaitu sikap sosial seseorang dalam menjangkau, memahami, dan memanfaatkan informasi yang berhubungan dengan bahasa, pengetahuan dan budaya melalui berbagai kegiatan, antara lain menyimak, membaca, menulis, melihat, dan berbicara untuk menciptakan kesejahteraan hidup (peradaban yang unggul). Literasi adalah peristiwa sosial yang dilengkapi kemampuan dimana makna dapat diciptakan dan di interpretasikan memalalui teks. Literasi membutuhkan sekumpulan kemampuan untuk menyampaikan dan memperoleh informasi dengan format tulisan. Kegiatan literasi diadakan untuk meluaskan keterampilan membaca supaya pengetahuan bisa dikuasai dengan lebih baik. Materi membaca berisi mengenai nilainilai moral, berupa kebijakan lokal, nasional, dan global yang dipaparkan sesuai jenjang perkembangan siswa.

Berikut pengertian dan definisi literasi dari beberapa sumber buku:

1) Menurut Rahayu (2016), literasi adalah segala aktivitas membaca dan menulis yang berhubungan dengan pengetahuan membaca serta menulis terkait dengan bahasa, pengetahuan, dan budaya. 
2) Menurut Romdhoni (2013), literasi adalah peristiwa sosial yang mengaitkan keahlian-keahlian khusus, yang diperlukan untuk mendapatkan dan menyampaikan informasi ke dalam bentuk teks.

3) Menurut Kern (2000), Literasi merupakan pemanfaatan pelaksanaan situasi sosial, dan historis, serta situasi kebudayaan demi mewujudkan dan menginterpretasikan definisi melalui teks.

4) Menurut Kemendikbud (2016), literasi adalah kemampuan mengakses, mencerna, dan menggunakan sesuatu dengan cerdas melalui beragam aktivitas, antara lain menyimak, menulis, membaca, melihat, dan berbicara.

b. Jenis-jenis Literasi

Menurut Setyawan (2018), berikut ini ada beberapa jenis literasi :

1) Literasi Digital, adalah penguasaan dasar secara teknis tentang cara menjalankan komputer dengan jaringan internet, dan disertai dengan memahami dan bisa berpikir kritis serta melaksanakan penilaian pada media digital serta dapat merancang suatu konten komunikasi.

2) Literasi Kesehatan, adalah kemampuan untuk mendapatkan, mengolah dan memahami informasi dasar tentang kesehatan serta layanan-layanan apapun yang dibutuhkan di dalam menciptakan keputusan kesehatan yang sesuai dengan ketentusn yang berlaku.

3) Literasi Visual, merupakan keahlian untuk menafsirkan, menegosiasikan dan menciptakan arti dari informasi yang berupa gambar visual. Literasi visual dapat pula kita definisikan sebagai kemampuan dasar untuk menterjemahkan teks yang tertulis di interpretasikan menjadi produk desain visual berupa gambar atau video.

4) Literasi Finansial, yaitu kemampuan di dalam menyelenggarakan penilaian terhadap informasi serta ketetapan yang efektif pada penggunaan dan juga penataan keuangan, dimana kemampuan yang dimaksudkan mencakup berbagai hal terdapat hubungan dengan bidang keuangan (Vhalery, Leksono, dan Irvan, 2019; Albertus, Leksono, dan Vhalery, 2020).

5) Literasi Kritikal, merupakan suatu pendekatan instruksional yang menyarankan untuk mengangkat perspektif secara responsif terhadap teks, dengan kata lain jenis literasi ini dapat kita pahami sebagai kemahiran untuk memotivasi para pembaca agar dapat aktif menganalisis teks serta mengungkapkan pesan yang menjadikan dasar argumentasi teks.

6) Literasi Data, merupakan kemampuan untuk mendapatkan keterangan dari data, lebih tepatnya kemampuan untuk mengartikan kerumitan analisis data.

7) Literasi Teknologi, adalah kemampuan seseorang agar dapat berkarya secara independen ataupun bekerjasama bersama orang lain dengan penuh tanggung jawab, efektif dan juga tepat dengan mengaplikasikan instrumen teknologi untuk mendapatkan, mengelola, selanjutnya mengintegrasikan, menilai, membuat serta mengkomunikasikan berbagai informasi.

8) Literasi Informasi, adalah kemampuan yang dimiliki oleh seseorang di dalam mengidentifikasi kapankah suatu informasi dibutuhkan dan keahlian untuk menciptakan serta mengevaluasi, kemudian memafaatkannya dengan efektif dan dapat mengkomunikasikan informasi yang dituju dalam bermacam-macam format yang jelas serta mudah untuk dipahami.

9) Literasi Statistik, merupakan keahlian untuk memahami statistik. Penafsiran mengenai hal ini memang dibutuhkan oleh masyarakat agar dapat memahami materi-materi yang disebarluaskan oleh media. 
Sedangkan Ferguson berpendapat, literasi terdiri dari beberapa jenis, yaitu sebagai berikut:

1) Literasi Dasar (Basic Literacy), literasi jenis ini bertujuan memaksimalkan kemampuan untuk berbicara, mendengarkan, membaca, menghitung, dan menulis. Dalam literasi dasar, kemampuan untuk mendengarkan, berbicara, membaca, menulis, dan menghitung (counting) berhubungan dengan keahlian analisis untuk menggambarkan sebuah informasi (drawing), mengkomunikasikan, memperhitungkan (calculating), serta mempersepsikan informasi (perceiving) berdasarkan interpretasi dan penentuan kesimpulan pribadi.

2) Literasi Perpustakaan (Library Literacy), setelah memiliki keahlian dasar kemudian literasi perpustakaan difungsikan untuk memaksimalkan Literasi Perpustakaan yang sudah ada. Tujuannya, pemahaman tentang adanya perpustakaan menjadi salah satu sarana memperoleh informasi. Literasi perpustakaan memiliki beberapa fungsi, antara lain : memahami pemanfaatan katalog dan pengindeksan, memanfaatkan koleksi referensi serta periodikal, memberikan pemahaman mengenai cara membedakan bacaan baik fiksi maupun nonfiksi, memahami penggunaan Dewey Decimal System untuk klasifikasi pengetahuan yang memberikan kemudahan dalam menggunakan perpustakaan, hingga memiliki pengetahuan dalam menafsirkan informasi ketika sedang menyelesaikan sebuah tulisan, pekerjaan, penelitian, ataupun mengatasi masalah.

3) Literasi Media (Media Literacy), merupakan kemampuan untuk mengenal berbagai macam bentuk media yang berbeda, seperti media cetak, media elektronik (media televisi, media radio), media digital atau media internet, serta memahami tujuan penggunaannya. Secara jelas saat ini dapat kita lihat di masyarakat, bahwa media cenderung sebagai sarana hiburan semata. Kita belum maksimal dalam memanfaatkan media sebagai corong untuk pemenuhan informasi mengenai pengetahuan dan memberikan kesan positif saat menambah pengetahuan.

4) Literasi Teknologi (Technology Literacy), adalah kemampuan mencerna kelengkapan yang menirukan teknologi seperti perangkat keras (hardware), perangkat lunak (software), serta adab dan etika dalam memakai teknologi. Berikutnya, dapat mengerti teknologi guna mencetak, mengakses internet, dan mempresentasikan. Dalam praktiknya, juga penafsiran memanfaatkan komputer (Computer Literacy) yang mencakup beberapa kegiatan yaitu mematikan dan menghidupkan komputer, menyimpan dan mengelola data, serta mempraktikan program perangkat lunak. Seiring dengan melimpahnya informasi karena pertumbuhan teknologi pada saat ini, dibutuhkan cara paham yang baik dalam mengelola informasi yang diperlukan masyarakat.

5) Literasi Visual (Visual Literacy), merupakan pemahaman tingkat lanjutan antara literasi teknologi dan literasi media, yang mengembangkan kemahiran dan kepentingan belajar menggunakan materi audiovisual dan visual secara kritis serta bermartabat. Pengertian dari materi visual yang setiap harinya memenuhi kehidupan kita, baik dalam internet, bentuk tercetak, maupun di televisi, haruslah terkontrol dengan baik. Bagaimanapun di dalam materi yang disuguhkan banyak manipulasi serta hiburan yang harus dipilah berdasarkan moral dan kepatutan. 


\section{Gerakan Literasi Sekolah}

Gerakan literasi adalah suatu tindakan ataupun aktifitas yang sifatnya partisipatif dengan mengaitkan warga sekolah (kepala sekolah, komite sekolah, guru, pengawas sekolah, peserta didik, orang tua atau wali murid peserta didik, tenaga kependidikan, media massa, penerbit, akademisi, masyarakat (misalnya tokoh masyarakat yang mampu memgemukakan keteladanan, dunia usaha, dan lainnya) dan yang memiliki kepentingan. Gerakan Literasi Sekolah adalah sebuah usaha yang dilakukan secara keseluruhan untuk melahirkan sekolah sebagai tempat organisasi pembelajaran yang anggotanya literat sepanjang hayat melalui pelibatan publik (Kemendikbud, 2016).

Terdapat tiga tahapan gerakan literasi sekolah menurut Kemendikbud (2016), yaitu sebagai berikut :

a. Tahap pertama (Pembiasaan)

Pembiasaan memiliki tujuan untuk menanamkan minat terhadap buku bacaan dan terhadap aktivitas membaca pada setiap warga sekolah. Penanaman minat baca adalah hal fundamental untuk pengembangan pada kemampuan literasi siswa. Aktivitas literasi pada tahap pembiasaan terdiri dari dua macam kegiatan membaca yang bermanfaat untuk kesenangan, yakni membacakan nyaring oleh guru dan membaca dalam hati. Secara umum, kedua aktivitas membaca mempunyai target, antara lain; meningkatkan kemahiran mencerna bacaan serta menperbaiki rasa percaya diri selaku pembaca yang baik, menambah rasa cinta baca pada saat diluar jam pelajaran, dan menumbuh kembangkan pemanfaatan berbagai sumber bacaan.

b. Tahap kedua (Pengembangan)

Tahap pengembangan dimaksudkan mengembangkan kemampuan mencerna bacaan dan menghubungkannya dengan pengalaman pribadi, mengolah kemahiran komunikasi secara kreatif dengan kegiatan menyimpulkan bacaan pengayaan, dan berpikir kritis. Kegiatan literasi di tahap pengembangan seperti kegiatan di tahap pembiasaan, yang membuat berbeda yaitu adanya kegiatan lima belas menit membaca (membacakan nyaring dan membaca dalam hati) dilanjutkan dengan kegiatan tindak lanjut di tahap pengembangan. Pada tahap pengembangan, peserta siswa didorong untuk menunjukkan peran serta emosi dan pikirannya dengan cara proses membaca melalui aktifitas produktif secara tulisan maupun lisan. Dan perlu diketahui bahwa aktifitas produktif ini tidaklah dinilai secara akademik.

c. Tahap ketiga (Pembelajaran)

Tahap pembelajaran dimaksudkan mengembangkan kemampuan mencerna teks dan menghubungkannya dengan pengalaman diri sendiri, berpikir dengan kritis, dan mengolah keahlian komunikasi secara kreatif dengan kegiatan memberikan tanggapan pada teks buku bacaan pengayaan serta buku pelajaran. Aktifitas membaca di tahap ini mewajibkan siswa membaca buku-buku nonteks yang bisa berupa buku tentang kegemaran, pengetahuan umum, teks multimodal, minat khusus. Buku laporan aktifitas membaca di tahap pembelajaran ini dipersiapkan oleh guru/wali kelas.

Berdasarkan tahapan dari gerakan literasi yang telah disebutkan dapat disimpulkan bahwa kegiatan literasi perlu ditanamkan sejak dini. Mulai dari pembiasaan, pengembangan hingga pembelajaran. Jika dibiasakan menanamkan kegiatan literasi sejak dini akan lebih mudah menyelesaikan tugas yang berkaitan dengan literasi. Jadi kegiatan literasi merupakan tindakan atau upaya untuk menambah wawasan, dan memahami peristiwa dengan cara membaca, melihat dan menganalisis segala sesuatu yang baru. 


\section{METHODS}

Penelitian ini dilakukan pada proses pembelajaran mata kuliah Filsafat Ilmu di Universitas Indraprasta pada semester ganjil tahun ajaraan 2020/2021 yang berlokasi di Jalan Nangka Raya No.58 C Tanjung Barat, Kota Jakarta Selatan. Yang menjadi subjek pada penelitian yaitu mahasiswa Fakultas Ilmu pendidkan dan pengetahuan sosial di program studi pendidikan ekonomi sebanyak 36 mahasiswa. Menurut Nazir (dalam Prastowo, 2011:186) metode deskriptif merupakan sebuah metode yang difungsikan untuk meneliti status sekelompok manusia, suatu sistem pemikiran, suatu objek, suatu set kondisi, ataupun suatu kelas peristiwa di era sekarang. Adapula pengertian metode kualitatif menurut Bogdan dan Taylor (dalam Moleong, 2011: 4) mengartikan metode kualitatif sebagai syarat penelitian yang memberikan hasil data deskriptif berupa tulisan atau lisan dari perkataan orang dan perilaku mereka yang diamati. Data yang diperoleh berupa perilaku manusia, kata-kata, serta gambar. Menurut Sukmadinata (2011: 60), penelitian kualitatif adalah penelitian yang berfungsi mendeskripsikan dan menelaah fenomena, aktivitas sosial, peristiwa, persepsi, sikap kepercayaan, cara berpikir secara individual ataupun kelompok. Sedangkan metode kualitatif menurut Bogdan dan Taylor (dalam Moleong, 2011: 4) mengartikan metode kualitatif sebagai prosedur penelitian yang menghasilkan data deskriptif berupa kata-kata lisan atau tertulis dari orang-orang dan tingkah laku yang diamati. Data yang dihasilkan berupa kata-kata, gambar, serta perilaku manusia. Sukmadinata (2011: 73) menyampaikan penelitian deskriptif kualitatif dimaksudkan untuk menggambarkan serta mendeskripsikan fenomena-fenomena yang ada, baik rekayasa manusia ataupun bersifat alamiah, intinya lebih memperhatikan mengenai kualitas, karakteristik, dan hubungan antar kegiatan. Selain daripada itu, penelitian deskriptif tidak terdapat manipulasi, perlakuan atau mengubah variabelvariabel yang diteliti, tetapi mendeskripsikan suatu kondisi sesuai dengan apa adanya. Jadi, perlakuan yang diberikan yaitu hanya penelitian itu sendiri, yang dilakukan melalui wawancara, observasi, dan dokumentasi. Jenis penelitian deskriptif kualitatif adalah sebuah metode penelitian yang memanfaatkan data kualitatif dan dijabarkan sejara deskriptif. Jenis penelitian model deskriptif kualitatif kerap digunakan untuk menganalisis kejadian, fenomena, atau keadaan secara sosial. Jenis penelitian deskriptif kualitatif adalah gabungan penelitian deskriptif dan kualitatif. Jenis penelitian deskriptif kualitatif memberikan tampilan hasil data tanpa proses manipulasi atau perlakuan lain sehingga apa adanya. Bagi Anda yang ingin mencari metode penelitian, jenis penelitian seperti deskriptif kualitatif bisa menjadi pertimbangan. Dalam penelitian kualitatif, data diperoleh dari berbagai macam sumber.

Teknik pengumpulan data ada bermacam-macam dan dapat dilakukan terus menerus hingga datanya jenuh. Pada proses ini peneliti berperan sebagai pengumpul data utama. Analisis data kualitatif itu bersifat induktif, yaitu suatu analisis berdasarkan pada data yang didapat, kemudian dikembangkan pola keterkaitan tertentu atau bisa menjadi hipotesis. Spradley berpendapat bahwa dalam penelitian kualitatif tidak memakai istilah populasi, tetapi dinamakan social situation atau situasi sosial yang terdiri dari tiga elemen, yakni pelaku (actors), tempat (place), dan aktivitas (activity) yang berinteraksi secara sinergis. Instrumen dalam penelitian ini yaitu observasi, dokumentasi, dan wawancara. Subjek penelitian adalah mahasiswa jurusan pendidikan ekonomi di Unindra. Mahasiswa melakukan kegiatan belajar mengajar secara daring karena terdampak pandemi Covid-19. Kondisi tersebut membuat Mahasiswa harus mampu lebih mandiri untuk bergerak aktif dengan memaksimalkan kegiatan literasi agar proses belajar berjalan secara optimal. Memberikan tugas untuk mencari bahan materi sendiri dari berbagai macam judul buku ataupun internet. Aktualnya menambah ilmu dan wawasan tidak selalu didapat dari kegiatan literasi, bisa juga dengan menonton vidio atau dengan melakukan 
praktek lainnya. Namun, untuk ilmu dasar yang paling mudah didapat yaitu dengan membaca, baik membaca buku ataupun membaca alat bantu seperti gadget dan laptop. Observasi dilakukan dengan memilih random kelas yang ingin dijadikan target penelitian, memilih di kelas yang mahasiswa berjumlah sedang dengan jumlah seimbang antara perempuan dan laki-laki. Kemudian dilakukan pemantauan terhadap perkembangan kelas tersebut selama menjalani metode kegiatan belajar ini. Mengamati dan berinteraksi secara berkala terhadap kesulitan mahasiswa selama metode belajar ini berlangsung.

\section{RESULTS \& DISCUSSION}

\section{Result}

Berdasarkan penelitian yang dilakukan kepada mahasiswa Unindra jurusan Pendidikan Ekonomi, upaya gerakan literasi ini cukup mendapat apresiasi yang baik oleh para mahasiswa. Hasil wawancara, observasi dan data nilai mahasiswa terhadap tugas dari pengajar mereka mengapresiasi semua tugas yang diberikan. Tugas yang diberikan kepada mahasiswa dengan membagi mahasiswa di kelas tersebut menjadi beberapa kelompok, kemudian memberinya masing masing judul materi untuk mereka presentasikan. Jadi, disetiap pertemuan terdapat kelompok melakukan presentasi. Materi yang dipresentasikan wajib menggunakan sumber yang jelas dengan mencantumkan sumber referensi minimal 5 sumber buku, dan 2 sumber jurnal. Dengan tugas tersebut, terlihat mahasiswa lebih menguasai materi yang mereka presentasikan. Terlihat perbedaan dari kepercayaan diri mahasiswa di kelas yang diberikan tugas presentasi dengan sumber referensi dan di kelas yang tidak diberikan tugas tersebut. Sesi tanya jawab setelah berlangsungnya presentasi juga lebih hidup di kelas yang berikan tugas sumber referensi. Walaupun kegiatan belajar mengajar dilakukan melalui aplikasi zoom komunikasi selama kegiatan belajar berjalan dengan baik.

\section{Discussion}

Penelitian ini menggunakan teknik mengajar yang dilakukan peneliti dengan memberikan materi presentasi kemudian mewajibkan mahasiswa untuk mencantumkan 5 sumber buku dan 2 jurnal. Setelah presentasi selesai dilakukan diskusi dan tanya jawab. Kegiatan ini juga mampu melatih mahasiswa sebelum mereka mengerjakan tugas akhir atau skipsi. Mahasiswa dibiasakan dengan penggunaan referensi buku yang sesuai dengan bahasan materi. Tidak hanya buku, jurnal menjadi referensi bacaan karena jurnal menjadi sumber informasi terbaru yang memberikan informasi yang valid.

Dengan pembiasaan tersebut akan melatih mahasiswa untuk membuat materi yang baik, memiliki sumber referensi jelas dan menghindari plagiat. Namun, beberpa mahasiswa menyampaikan bahwa dengan cara seperti ini lebih lambat menyelesaikan tugas karna mereka tidak bisa dengan mudah mendapatkan bacaan. Mereka harus memperhatikan sumber bacaan dengan baik, dan harus memahami apakah sumber bacaan tersebut valid atau tidak. Selain difungsikan untuk menyelesaikan tugas, membaca tulisan, artikel ataupun jurnal membuat mahasiswa memiliki wawasan yang luas, pikiran terbuka dan pengetahuannya bertambah. Dengan demikian mahasiswa akan menjadi lulusan yang memiliki kompetensi yang baik kedepannya. Pembelajaran daring yang dilakukan selama adanya pandemi covid-19 ini memberikan pengalaman kepada mahasiswa bahwa sebagai mahasiswa mereka harus mempunyai kemandirian dalam kegiatan belajar mengajar dan menambah wawasannya. 
Dalam pelaksanaan upaya gerakan literasi pada pembelajaran daring tidak mudah untuk dilaksanakan oleh mahasiswa, karena mahasiswa masih semester tiga. Mereka belum memahami betul cara mencari sumber bacaan yang sesuai dengan materi yang akan mereka buat. Di kondisi tersebut, peran serta pengajar untuk terus memberikan arahan, motivasi dan pemahaman sangat penting. Selain itu, evaluasi hasil artikel yang telah mahasiswa buat juga harus di evaluasi dengan baik agar mereka tidak dengan mudah melakukan plagiat terhadap artikel orang lain. Jika mahasiswa mengetahui pengajar tidak melakukan evaluasi, dikhatirkan mahasiswa tidak akan mengetahui dimana letak kekurangan dan kesalahannya. Implikasi dari gerakan literasi ini yaitu mahasiswa menjadi memahami teknik menulis menggunakan referensi yang tepat, mampu menentukan sumber bacaan yang dapat dijadikan bahan referensi, mahasiswa memiliki tingkat kompetensi yang lebih baik dengan lebih banyak membaca buku dan jurnal, mahasiswa lebih percaya diri untuk menulis tugas akhir atau skripsi nantinya.

\section{CONCLUSION}

Untuk mengasah kemampuan mahasiswa perlu pembiasaan dengan tugas harian, pengembangan dengan mengaitkan tugas literasi dengan materi mata kuliah, pembelajaran dengan memberikan inovasi tugas berdasarkan mata kuliah yang di ikuti. Selain dari ketiga tahapan tersebut, upaya meningkatkan kegiatan literasi dikalangan mahasiswa dapat dimaksimalkan dengan evaluasi dari pihak pengajar agar mahasiswa selalu termotivasi dan terus mengembangkan kompetensinya. Jika metode pembelajaran ini dilakukan di semua mata kuliah, yang terjadi mahasiswa akan menjadi mahasiswa yang cinta mebaca. Karna membaca dapat dibudayakan dengan membiasakan diri untuk terlibat dengan buku. Dengan cinta membaca, mahasiswa berwawasan luas dan memiliki percaya diri yang tinggi.

\section{REFERENCES}

Albertus, S. S., Leksono, A. W., \& Vhalery, R. (2020). PENGARUH LITERASI KEUANGAN DAN LINGKUNGAN KAMPUS TERHADAP MANAJEMEN KEUANGAN PRIBADI MAHASISWA. Research and Development Journal of Education, 1(1), 33-39.

Kementerian Pendidikan dan Kebudayaan. (2016). Buku Saku Gerakan Literasi Sekolah. Jakarta: Kemendikbud.

Kern, Richard. (2000). Literacy and Language Teaching. Oxford: Oxford University Press.

Moleong, L. J. (2011). Metodologi Penelitian Kualitatif Edisi Revisi. Bandung: PT. Remaja Rosdakarya.

Prastowo, Andi. (2011). Metode Penelitian Kualitatif dalam Perspektif Rancangan. Penelitian. Jogjakarta: Ar-Ruzz Media.

Rahayu, Triwati. (2016). Penumbuhan Budi Pekerti Melalui Gerakan Literasi Sekolah. The Progressive and Fun Education Seminar. Online: publikasiilmiah.ums.ac.id

Romdhoni, Ali. (2013). Al-Qur'an dan Literasi: Sejarah Rancang-Bangun Ilmu-Ilmu Keislaman. Depok: Literatur Nusantara.

Setyawan, Ibnu Aji. (2018). Kupas Tuntas Jenis dan Pengertian Literasi. Online: gurudigital.id

Sukmadinata, N.S. (2011). Metode Penelitian Pendidikan. Bandung: Remaja Rosadakarya. 
Vhalery, R., Leksono, A. W., \& Irvan, M. (2019). Pengaruh Literasi Keuangan, Usia, dan Bimbingan Orang Tua terhadap Pengelolaan Uang Saku Mahasiswa UNINDRA. Jurnal Pendidikan Ekonomi, 12(1), 10-17. 